\title{
SLOVENSKI ARHITEKT CIRIL METOD KOCH V EVROPSKI PERSPEKTIVI
}

Ključne besede: arhitekt Ciril Metod Koch, historicizem in secesija v ljubljanski ter dunajski arhitekturi, arhitekt Karl von Hasenauer, reviji Ver Sacrum in Der Architekt, knjige ornamentov, Franz Sales Meyer.

\section{Most med Liubliano in Dunajem, med starim in novim}

Slovenski arhitekt in urbanist Ciril Metod Koch (1867, Kranj-1925, Ljubljana; slika 1), predhodnik slovenske moderne arhitekture, ki je skoraj tri desetletja deloval $\mathrm{v}$ ljubljanskem gradbenem uradu, je načrtoval profane stavbe v Ljubljani, Celju, Kamniku, Novem mestu in Opatiji (javne zgradbe, privatne meščanske hiše, vile). Dotaknil se je tudi province (podeželske vile, cerkev v Vipavi, Bohinjski most). Njegovo življenje in delo sta znana iz pisem, na podlagi katerih mu lahko pripišemo več kot petdeset zgradb. ${ }^{1} \mathrm{~V}$ pismih zasledimo, da gre za načelnega, strogega in iznajdljivega arhitekta, ki si je zaradi številnih pomembnih naročil nakopal tudi zavist tekmecev. Pisma so edini zanesljivi pisni vir, kjer je možno izslediti njegovo profesionalno pot, manj pa je podatkov o njegovem zasebnem življenju, temperamentu, prijateljskih stikih ipd. ${ }^{2}$ Kljub dejstvu, da je bil oče šestim otrokom, in relativno kratki življenjski dobi je njegov opus obsežen.

1 ZAL, LJU/494, Zbirka personalnih spisov.

2 Celotna arhitektova korespondenca je na voljo v Ljubljanskem zgodovinskem arhivu, $\mathrm{v}$ elektronski obliki pa je na voljo v celoti kot priloga magistrske naloge (Simonišek, 2007, 183-226). 


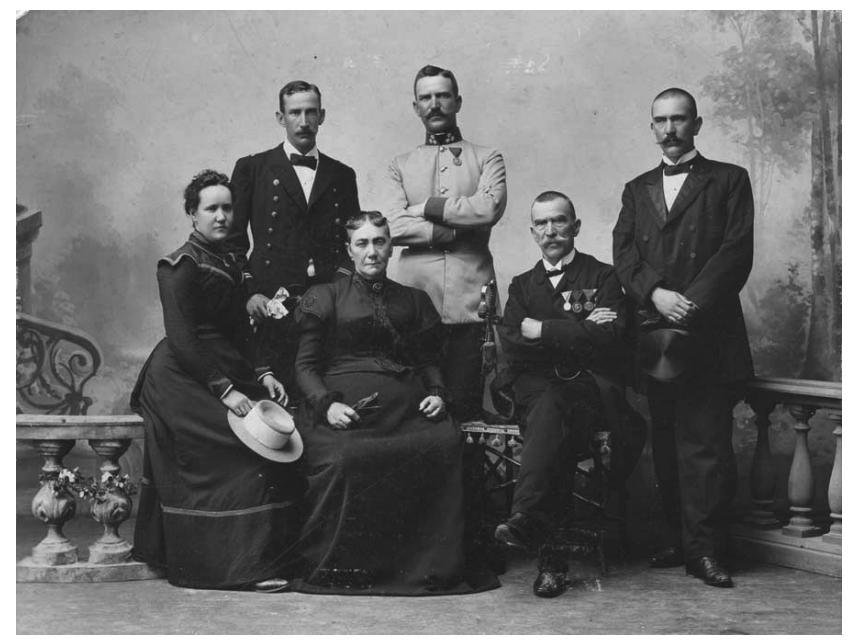

slika 1: C. M. Koch z družino (arhitekt je skrajno desno) vir: arhiv Jaka Bonča

Burckhardt razdeli spremembe na Dunaju v obdobju dvojne monarhije v tri skupine; prvo obdobje, ki traja od 1867 do 1897, zaznamujejo družbene spremembe, rast buržuazije in historicizem v umetnosti; drugo obdobje, ki traja do leta 1906, zaznamujejo upori slovanskih narodov, transcendentalna miselnost in secesija; tretje obdobje, ki traja do začetka prve svetovne vojne, je čas, ko podvomijo v ornament, v arhitekturi se uveljavlja funkcionalizem (Burckhardt, 1985, 57-69). Kochov razvoj sicer lahko razumemo $\mathrm{v}$ omenjenih intervalih, $\mathrm{z}$ nekajletnim zamudništvom, pri čemer je treba poudariti, da se ga zadnje obdobje ni dotaknilo, kar nenazadnje spregovarja estetika njegovih stavb. Vendar njegovo slogovno pot ni možno poenostaviti, saj se je tudi v zrelem obdobju loteval zgradb, ki se ozirajo po historicizmu in so presenetljivo bolj doživete kot zgodnje; ta pojav je treba kvečjemu pripisati željam naročnikov. Historicizem, ki se mu je iztekala zlata doba, se je še vedno opiral na tradicijo antike, gotike, renesanse ali baroka. Koch ga je neposredno doživljal za časa svojega študija v prestolnici monarhije. Ko se je vrnil, je začel risati načrte za zgradbe $\mathrm{v}$ tem duhu, še največkrat se je približal renesančnemu občutenju: npr. hiša Policije, Zhubrova hiša, vila Koch-Pribil, ubožnica. Nekaj let kasneje, za časa delovanja ljubljanskega župana Ivana Hribarja, pa se je močno 
zgledoval po secesijski modi, ki je preplavila naše mesto. Tedaj so tudi njega kot številne druge arhitekte, ki so delovali v Ljubljani, dosegli impulzi karizmatičnega Otta Wagnerja, najvplivnejše osebnosti v arhitekturnem pogledu na takratnem Dunaju, pod okriljem katerega sta se šolala Jožef Plečnik in Maks Fabiani. Ni potrebno poudarjati, da je Koch avtor mnogih najkvalitetnejših secesijskih stavb v Sloveniji (npr. Čudnove, Pogačnikove, Vodnikove, Hauptmannove hiše, hranilnice v Radovljici idr.), ki v dekorativnem pogledu zrcalijo dunajske vplive. ${ }^{3}$ Študijsko srečanje s prinašalcem moderne arhitekture, ki je začel svoja predavanja leta 1894, je Koch za štiri leta zgrešil, vendar je »wagnerjanski estetiki« skozi posredništvo prisluhnil kasneje v Ljubljani.

Mladega Kocha je na dunajski akademiji moral zaznamovati arhitekt baron Karl von Hasenauer, ki je bil v pedagoškem pomenu Wagnerjev predhodnik. Glede na potek študija (1888-90) se je morebiti udeleževal njegovih predavanj, ki so se vrstila na akademiji vse do leta $1894 .{ }^{4}$ Tu naj bi prišel v stik z mojstrovimi pedagoško-filozofskimi smernicami, zagotovo pa se je navduševal nad estetiko historicizma, ki so jo na akademiji takrat še trezno zagovarjali. Koch se je za razliko od drugih dveh pionirjev slovenske arhitekture, ki sta prišla v prestolnico nekaj let za njim, po končanem študiju nemudoma vrnil v Ljubljano. Edini projekt, ki je izpod njegovih rok nastal na Dunaju, je mavzolej Ginzelmayer, ki pa ga žal zaradi pomanjkanja podatkov ni možno natančneje locirati. ${ }^{5}$ Po vrnitvi je sprva nekaj let sodeloval s priznanim ljubljanskim gradbenikom Filipom Supančičem, ki je aktivno prevzemal pomembna naročila na našem ozemlju. ${ }^{6} \mathrm{~V}$ nasprotju s Plečnikom in Fabianijem ni nikoli poučeval, večino življenja je bil zaposlen kot arhitekt v mestnem gradbenem uradu. Tukaj se je v času popotresne Ljubljane soočal z dinamičnim, včasih birokrat-

3 V strokovni literaturi so Kocha obravnavali kot secesijskega arhitekta, čeprav slogovno temu pripada približno polovica njegovih zgradb. To je treba pripisati dejstvu, da je dolgo bil znan le secesijski del njegovega opusa. Pri prestrezanju secesijskih novosti se Koch ni oprl le na novosti, ki jih vpeljeval Wagner; zanemarljiv ni vpliv Josepha Marie Olbrica in Friedricha Ohmanna. Več o tem Simonišek (2007, 156-173). 
sko napornim delom (pregledovanje načrtov, nadzor nad stavbami ipd.). Podobno kot njegov slikarski sodobnik Ivan Vavpotič, ki je bil slogovno razpet med meščanskim realizmom in sprejemanjem secesijskih prvin na likovnem področju, je Koch ves čas lovil ravnotežje med starim in novim, akademskim in modnim (Komelj, 1987, 15). V slovenskem prostoru takrat ni bilo pogojev, da bi arhitekt sodeloval zgolj z enim naročnikom. Zagotovljeno mecenstvo, kot ga je npr. bil deležen katalonski arhitekt Antoni Gaudi, ki ga je podprl bogat kapitalist Eusebi de Güell, je bilo izjema (Zerbst, 1997, 24).

Koch se je povezoval z mnogimi vplivnimi osebnostmi v Ljubljani: poznal je vse tri župane, ki so se menjali za časa njegovega življenja (Grassellija, Hribarja in Tavčarja), družino Auer, ki je bila lastnica in ustanoviteljica pivovarne v Ljubljani, nemškega barona Friedricha von Borna, uspešne ljubljanske tovarnarje, povzpetne obrtnike, ki so gradili udobne meščanske vile, ustanovitelje posojilnic in bančnike. ${ }^{7} \mathrm{~V}$ nadaljevanju bom poskušal nakazati odgovore na tri vprašanja, ki so vezana na mednarodne vplive: prvič, kakšna je povezava med Kochom in enim od vodilnih predstavnikov historicistične struje na Dunaju, torej njegovim učiteljem; drugič, ali je morda Koch ideje za ikonografske kompozicije na fasadah črpal iz mednarodnih revij; in tretjič, v kolikšni meri je Koch pri dekoraciji ljubljanskih stavb upošteval knjigo ornamentov Franza Salesa Meyerja?8

\section{Aristokratski historicizem dvornega arhitekta in profesorja Karla von Hasenauerja}

Karl von Hasenauer (1833-1894; slika 2) je bil na dunajski Akademiji za upodabljajoče umetnosti, kjer se je Koch specializiral za arhitekturo, med najvplivnejšimi osebnostmi. Predpostavimo, da je dejansko bil njegov učitelj, torej, da sta se kot učenec in učitelj srečevala v predavalnicah (Wacha

7 ZAL, LJU/494, Zbirka personalnih spisov.

8 Gre za knjigo, ki jo je imel arhitekt na svoji knjižni polici. Priročnik je eden izmed redkih predmetov iz arhitektove zapuščine in je v lasti družine Bonča. Priročnik je podpisan in datiran: Koch ga je kupil na Dunaju za časa študija leta 1889. 
in Prašelj, 1969, 156). ${ }^{9}$ Podatek o Kochovem šolanju potrjuje korespondenca, kjer je med drugim omenjeno tudi spričevalo pridobljeno na tej instituciji. ${ }^{10}$ Skupaj z nemškim arhitektom in teoretikom Gottfriedom Semperjem je Hasenauer odigral osrednjo vlogo pri prenovitvi cesarskega foruma.

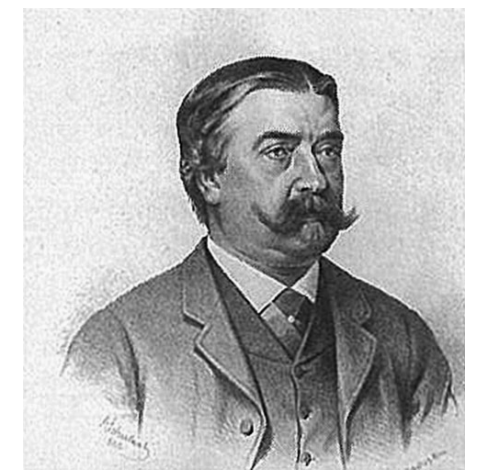

slika 2: Arhitekt Karl von Hasenauer

vir: http://aeiou.iicm.tugraz.at/aeiou.encyclop.h/h234020.htm

Za časa poučevanja je bil uveljavljen zastopnik poznega historicizma na Dunaju, v javnosti so ga imenovali kar »stavbeni Makart «, ${ }^{11}$ sicer najbolj znan in uspešen slikar v drugi polovici 19. stoletja na Dunaju (Huici, 1989, 10). ${ }^{12}$ Dinamično dunajsko okolje, čeprav $\mathrm{z}$ vidika evropske perspektive $\mathrm{v}$ marsičem tudi neliberalno in utesnjujoče, v katerem je Koch zorel, in prenašanje tovrstnih vzgibov v Ljubljano lahko razumemo skozi Hasenauerjevo posredovanje. Tudi če izključimo možnost srečanja, ne moremo mimo dejstva, da je Koch v prestolnici videl reprezentativne stavbe, ki so takrat (na)stale, in da ga je dunajsko umetniško ozračje močno zaznamovalo. Občudoval je lahko Hasenauerjeve projekte, nastale v sodelovanju s Semperjem, ki jih je bilo pred letom 1890 dovolj (Mallgrawe, 1996, 351-352). Ko

9 Ni povsem jasno, ali avtorja leksikona to ugotovitev skleneta na podlagi časa Kochovega študija ali se morda na podlagi dokumenta (kot je npr. spričevalo) opirata na kaj bolj empiričnega.

$10 \mathrm{~V}$ pismih se spričevalo sicer večkrat omenja, ni pa priloženo, zato tudi ni podatkov o predmetih in profesorjih. Več o tem: ZAL, LJU/494, Zbirka personalnih spisov.

11 Vir podatka: http://www.aeiou.at/aeiou.encyclop.h/h234020.htm.

12 Primerjava med Hasenauerjem in Hansom Makartom zgolj dokazuje popularnost prvega. 
je leta 1888 prispel v metropolo ob Donavi, so odprli neobaročno zgradbo Burgtheater, ki je bila zgrajena po baronovih načrtih. ${ }^{13} \mathrm{~V}$ centralno zasnovani stavbi mestnega gledališča si je Koch že lahko ogledal zgodnje Klimtove poslikave, $\mathrm{v}$ katerih še ni bilo klasičnega secesijskega vzdušja. Klimt, ki je že leta 1890 prejel cesarsko nagrado za alegorične poslikave v teatru, je postajal vse bolj cenjena osebnost (Huici, 1989, 10). V poslikavah notranjščine dunajskega teatra se pojavljajo tudi zgradbe, ki so jih tedanji arhitekti imeli za vzor historicizma in so bile predmet neformalne študije; npr. Klimtova slika Taeter $v$ Taormini (Huici, 1989, 29).

Še bolj impozantno sta se vzpenjali neorenesančni stavbi Kunsthistorisches in Naturhistorisches Museum, ki so ju pod pokroviteljstvom cesarske družine odprli leto za tem, ko se je Koch vrnil v Ljubljano. ${ }^{14}$ Zgradbi umetnostnozgodovinskega in naravoslovnega muzeja, zgrajeni med leti 1872 in 1891, sta postali vzor za mnoge obetavne arhitekte, Semper in Hasenauer pa sta se kot sodelavca pri gradnji muzejev zapletla v spor. Končni izid egocentričnosti je bil, da sta si razdelila naloge in podpisala sporazum, ki je določal različne vloge pri gradnji muzejev: Semperju so bile zaupane naloge, povezane $z$ umetniškim delovanjem, medtem ko je Hasenauer nadziral gradnjo in skrbel za administrativna dela (Mallgrawe, 1996, 352). Za oblikovanje izjemno nadarjen mož je prezgodaj umrl, da bi lahko doživel revolucionarne spremembe $\mathrm{v}$ arhitekturi, ki so se razcvetele s secesijo. Bil je blizu peripetijam na habsburškem dvoru, kajti osebno je poznal cesarja Franca Jožefa I. in bližnje sodelavce. Poleg omenjenih naročil je njegov opus relativno skop. Leta 1867 je zgradil Avstro-Ogrski paviljon za svetovno razstavo v Parizu, leta 1873 paviljon za razstavo na Dunaju. Je tudi avtor intimnih stavb na Dunaju: npr. Azienda-Hof in Palače Lützow. ${ }^{15}$ Zadnje pomembno naročilo je uresničil v bližini Schönbrunna leta 1881, kjer je postavil Hermesvillo. Sredi vrta stoječi romantični dvorec, poimenovan po bogu Hermesu, je bil darilo soprogi Elisabethi.

Preden razgrnemo povezave med njima, je treba vedeti, da je Koch eklektik, ki je črpal ideje iz različnih virov. Od svojih vzornikov je vedno povzemal

13 Vir podatka: $h t t p: / / w w w . s t a d t-w i e n . a t /$ index.php?id=burgtheater-wien.

14 Vir podatka: http://www.khm.at/homeE107.html.

15 Vir podatka: http://www.artnet.com/library/03/0368/T036837.asp. 
redukcijsko. ${ }^{16}$ Osredotočil se je na določen fragment in ga postavil v nov kontekst. Zaman je pričakovati, da bi Koch v Ljubljani z eklatantnim zamahom preslikal učiteljev dunajski historicizem, kajti naročila so bila manj pompozna, dimenzije stavb manjše, denar za bogatejšo dekoracijo vil redkost. Iz teh razlogov se je pri "preslikavanju « posluževal rešitev, ki so ustrezale realnim izhodiščem. Za začetek naj služi primerjava dveh njegovih stavb z dunajsko Palača Lützow, ki se nahaja se na Bösendorferstrasse 13 (slika 3).

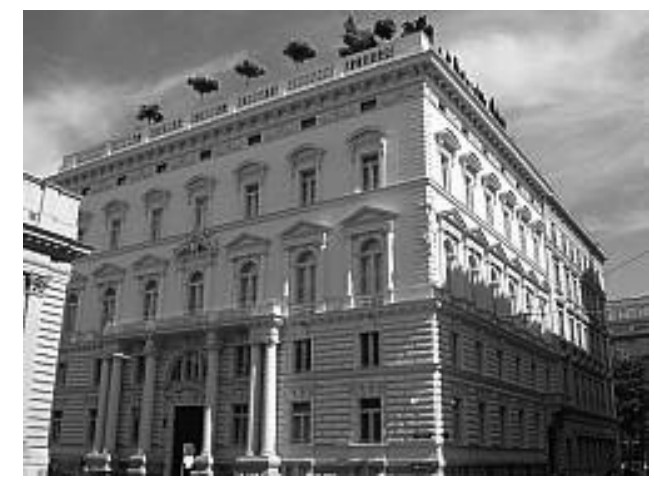

slika 3: Palača Lützow

vir: http://www.planet-vienna.com/spots/Palais/luetzow/luetzow.htm

Vplivni umetniški kritik Carl Lützow je leta 1870 naročil palačo, ki se na zunaj ravna po merilih italijanske renesanse. ${ }^{17}$ Hasenauerjev princip oblačenja fasadne ploskve je tukaj izveden klasično, skoraj »michelangelovsko«. Analiza palače pokaže številne sorodnosti z nekaterimi ljubljanskimi zgodnjimi stavbami, načrtovanimi še pred Kochovim vstopom v secesijo. Za izhodišči lahko vzamemo Kochov načrt za nekdanjo Stubenbergovo ubožnico na Dunajski cesti iz leta 1900 (slika 4) in bivšo Kmetsko posojilnico na križišču Dunajske in Dalmatinove iz leta 1906 (slika 5).

16 Arhitekt Ivo Spinčič je poudarjal Kochovo vplive s strani dunajskega arhitekta Friedricha Ohmanna (povzeto po pogovoru z dr. Jakom Bončo).

17 Vir podatka: http://www.planet-vienna.com/spots/Palais/luetzow/luetzow.htm. 


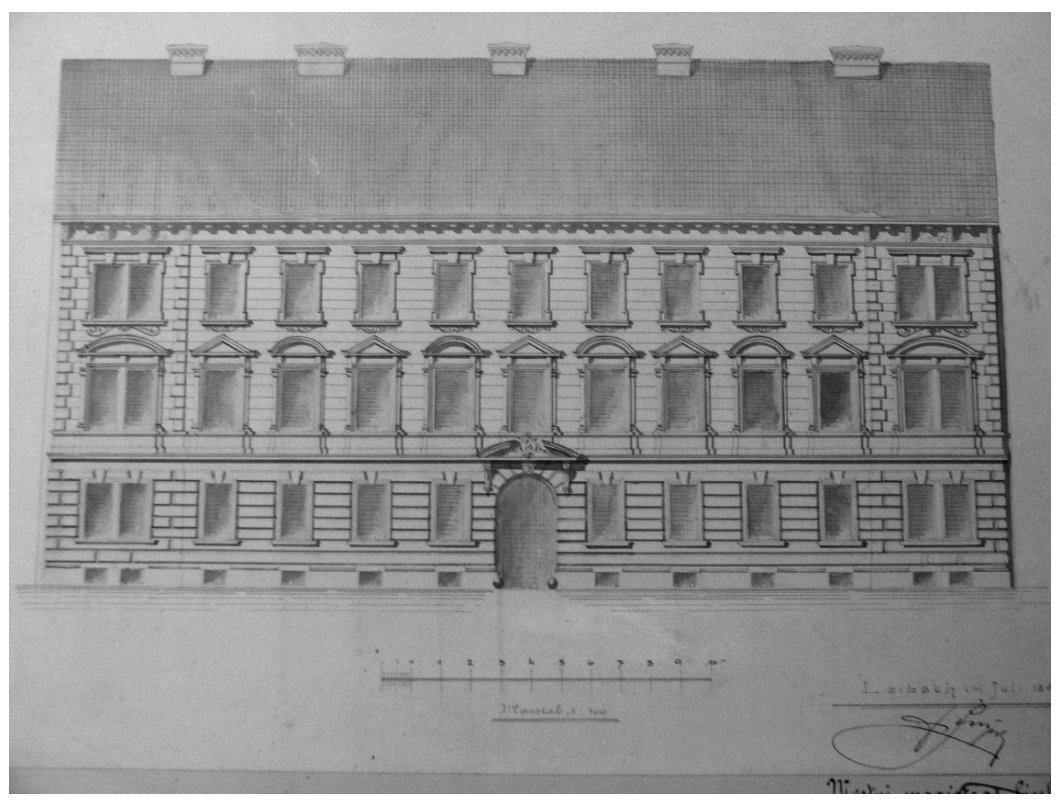

slika 4: Načrt za nekdanjo Stubenbergovo ubožnico vir: arhiv Robert Simonišek

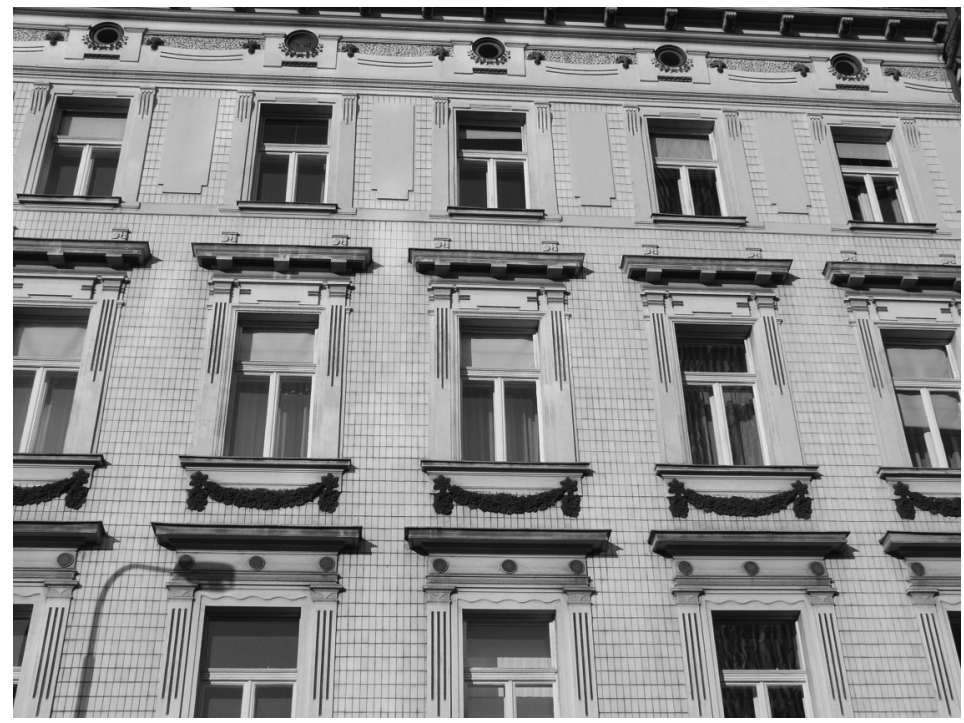

slika 5: Bivša Kmečka posojilnica vir: arhiv Robert Simonišek 
Obe stavbi še stojita, njuna namembnost je spremenjena. Kombinacijo polkrožnih in trikotnih zaključkov nad okni je Koch uporabil večkrat, ne le pri ubožnici. Kompozicija girland na vrhnjem delu fasade Palače Lützow je sorodna ornamentu tik pod streho nekdanje Kmetske posojilnice. Podobnosti med palačo in slovensko posojilnico, ki sodi že v zrelo secesijsko Kochovo obdobje, najdemo tudi na zaključku strehe, kjer sta oba arhitekta uporabila priljubljen toskanski tip rešitve. Koch je v zgodnji fazi intenzivneje črpal znanje iz dunajskega kroga, kjer se je znašel v šolskih letih. V zrelosti je pridobljeno znanje vedno bolj potiskal v ozadje in se prilagajal sodobnejšim trendom secesije, čeprav eksplicitnih nagnjenj do zgodovinskih slogov ni nikoli zanikal.

\section{Vpliv mednarodnih revij na dekoracijo Kochovih stavb}

Okoli leta 1900 so bile revije glavni medij obveščanja o aktualnih dogodkih na umetniških področjih. Krojile so okus v strokovnih krogov, arhitektom, ki niso bili na Dunaju, so omogočale seznanjanje z novostmi. Vloga mednarodnih revij v ljubljanski secesijski arhitekturi je bila med raziskovalci že nakazana (Prelovšek, 1996, 597-600), zato bom na tem mestu opozoril na dvoje. Za Kocha so revije in fotografije, ki jih je verjetno tudi dobival od svojih dunajskih kolegov, bile še toliko usodnejše, ker po študiju ni več potoval v tujino. ${ }^{18}$ Ustavil bi se pri dunajskih revijah Ver Sacrum, katere izhajanje med leti 1898-1903 zaznamuje višek secesije in Der Architekt, ki je izhajala med leti 1895-1919. Reviji sta bili dostopni arhitektom, ki so delovali na ozemlju današnje Slovenije (npr. Plečnik jih je poznal, saj so nekateri izvodi so del dane njegove zapuščine). ${ }^{19}$

Ime prve nosi simbolne konotacije, saj v latinščini pomeni »sveto pomlad« (heiliger Fruhling). ${ }^{20}$ Prispevke zanjo so pripravljali pomembni ume-

$18 \mathrm{~V}$ pismih ni nobenega podatka o potovanjih v tujino po študiju.Več o tem: ZAL, LJU/494, Zbirka personalnih spisov.

19 Številni izvodi revij se danes nahajajo v knjižnicah Plečnikovega muzeja in Slovenske akademije znanosti in umetnosti.

20 Klaus Zelewitz, Barbara Schober, Ver Sacrum-Das Ebenbild der Secession, Auswenderung der Kunst? Secession-Klimt, Schiele, Kokoschka, Literatur der Wiener Moderne, vir podat- 
tniki secesije. Poleg teksta je vsebovala originalne barvne grafike. Teme so bile različne: objavljali so skice, načrte stavb, mostov, vrtov, razstavnih paviljonov, prispevke o modi, poezijo, eseje, spise in umetniško kritiko. Ver sacrum je pritegnila več sodelavcev, uveljavljenih literatov, kot so bili npr. Herman Bahr, Reiner Maria Rilke, Hugo von Hofmannstal, Richard Schaukal. Teksti so bili razporejeni v skupine: pamfleti, memorandumi, umetnostnozgodovinski prispevki, literarni fragmenti, spisi o članih gibanja Secesija, poročila o razstavah, novice o izhajanju revij, časopisov in knjig ipd. Revija je poročala o težavah, o nesporazumih v avstrijskem umetniškem življenju, spopadla se je s konkretnimi problemi umetnikov, ki so izkazovali proteste na umetniškem področju. Tarča kritik so bili birokratski postopki, način izobraževanja umetnikov, financiranje umetniškega dela, načini uveljavljanja umetnikov v družbi ipd. ${ }^{21}$

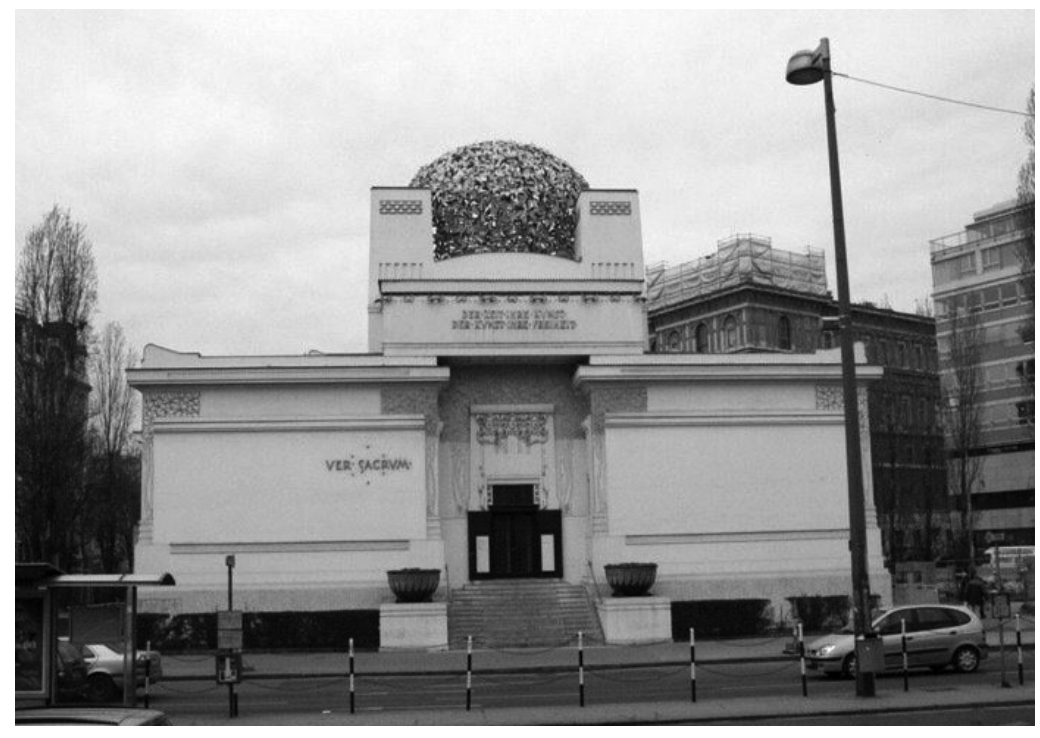

slika 6: Hiša Secesije

vir: http:// www.GreatBuildings.com

ka: http://www.sbg.ac.at/ger/zelewitz/liwimo/docu/frei-old/generated/pdf/lecture.pdf, 2000, 267-269.

21 Opis je nastal s pomočjo izvodov revij, ki se nahajajo v Plečnikovem muzeju. 
Ver sacrum $\mathrm{v}$ ikonografskem pogledu ponuja številne namige, ki so se materializirali v ljubljanski secesijski arhitekturi, saj je to revija, ki je poosebljala ideale tega evropskega gibanja. Ko je Koch izrisoval načrte za glavne secesijske stavbe, je moral biti seznanjen vsaj z nekaterimi izvodi. Pri načrtovanju Čudnove hiše leta 1902 (sliki 7 in 8) se je oprl na dve stavbi Josepha Olbricha. Poleg Josepha Hofmanna in že omenjenega Wagnerja je bil Olbrich vodilni arhitekt dunajske secesije. Pri tem se je Koch lahko zgledoval kar po fotografijah slavne Hiše secesije, simbolne stavbe iz leta 1896 (slika 6), ki so bile prikazane v večih izvodih. Najbrž je bil seznanjen tudi s skico hiše Hermanna Stohra (slika 9) v avstrijskem St. Poltnu iz leta 1899 (Ver Sacrum, 1899). Slovenski arhitekt je iskal vzpodbude v obeh zgradbah, vendar jih je močno modificiral in prilagodil želji slovenskega naročnika (Prelovšek, 1996, 600).
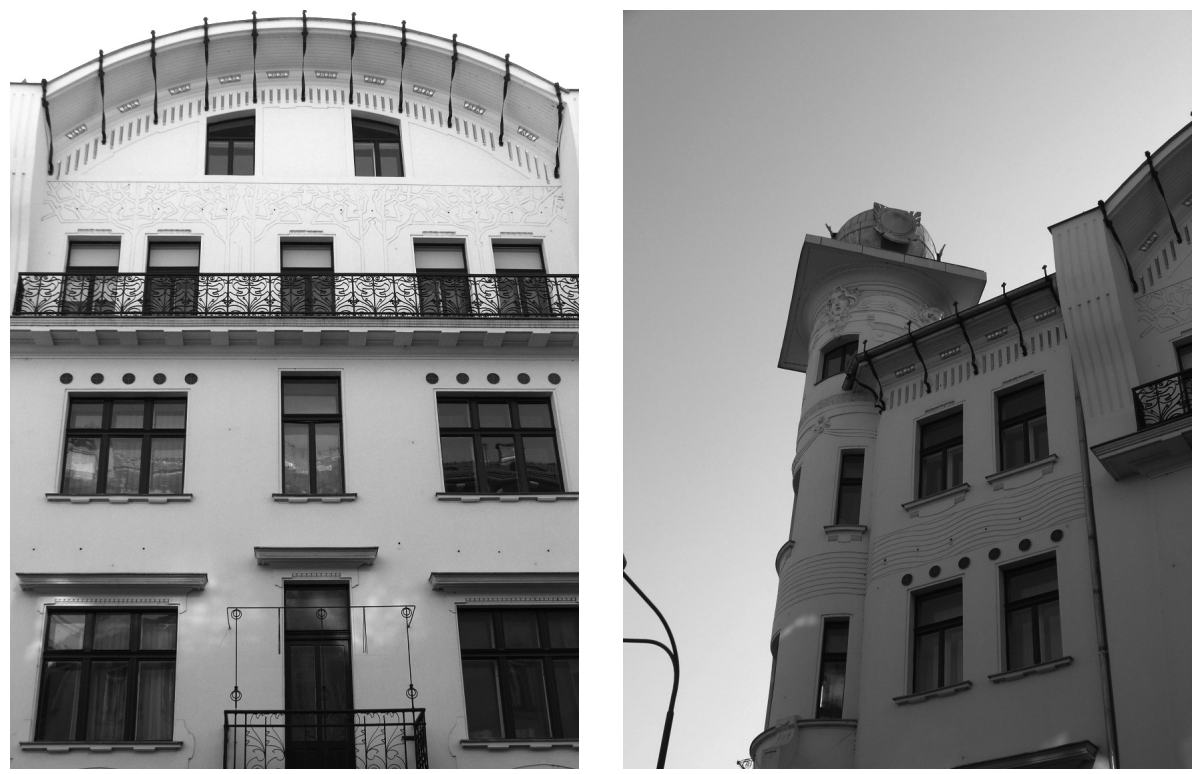

sliki 7 in 8: Čudnova hiša vir: arhiv Robert Simonišek 


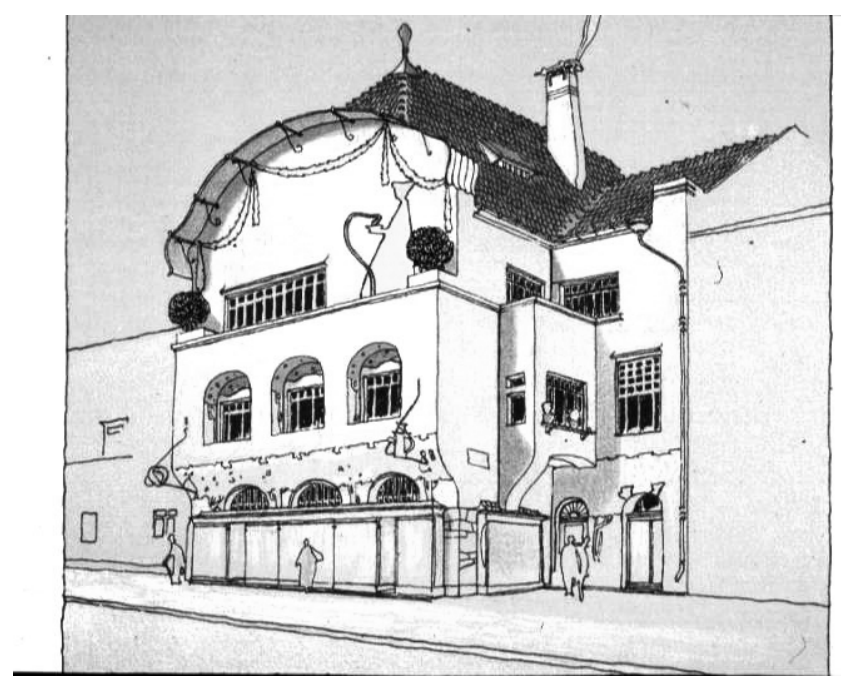

slika 9: Hiša Hermanna Stohra vir: revija Ver Sacrum, Wien, 1899

Revija Der Architekt je vsebinsko presegala teme, ki so bile vezane zgolj na arhitekturo: načrti za hotele, banke ali stanovanjske hiše, skice parkov, opisi stanja dvorcev, vil ipd. Za razliko od prve v ospredje ni postavljala le secesije. Kljub številnim poskusom po decentralizaciji umetnosti v monarhiji, političnim nasprotovanjem ter naraščajočim nacionalnim gibanjem je z estetsko neobremenjenostjo, pestrostjo pogledov in s strokovno kritičnostjo širila nove poglede. Mnoge zamisli, ki so bile nakazane, so ponovno zrasle, zaživele so v spremenjeni varianti na povsem drugem koncu Evrope. Če so se zgodnji zvezki še ukvarjali z značilnostmi imperialnega sloga, so ti poudarki z leti bledeli, se selili v objave kritičnih prikazov, refleksij, povezanih z moderno arhitekturo in novimi tipi stavb. Občuten in pomenljiv vsebinski premik, ki sta ga zaznamovala kriza 1. svetovne vojne kot tudi smrt Otta Wagnerja, se je v reviji kazal v zmanjšanem številu strani. Poleg velikih pionirjev moderne arhitekture (Loos, Bahrens, Kotera) so se začeli pojavljati tudi članki o manj znanih osebnostih na področjih grafike in slikarstva. ${ }^{22}$ Revija je bila zaslužna za seznanjanje z novostmi, ki so prihajale

22 Pri tem splošnem opisu vzdušja revije se opiram na izvode, ki so dostopni na Umetnostnozgodovinskem inštitutu Franceta Steleta ZRC SAZU. 
iz Anglije in Amerike. Poskušala je ovrednotiti in rehabilitirati kulturno dediščino, ki je bila zapostavljena (rusko gradbeništvo, hrvaška podeželska arhitektura, švedska arhitektura ipd). Arhitekti so se lahko seznanjali s prevodi Stendhalovih opisov italijanskega tipa lepote, s skicami, ki so nastajale na potovanjih arhitektov ipd. Prispevkom so sledili aforizmi vplivnih mož kot so bili Auguste Rodin, Arnold Böcklin, John Ruskin, Walter Crane, William Morris in Henry van de Velde.

Koch je moral poznati tudi to revijo. Ko se je leta 1902 spraševal, kaj naj doda nad glavnim vhodom skoraj klasicistično ploskovite fasade Pogačnikove hiše (slika 10), je pri tem lahko izbiral med mnogimi motivi.

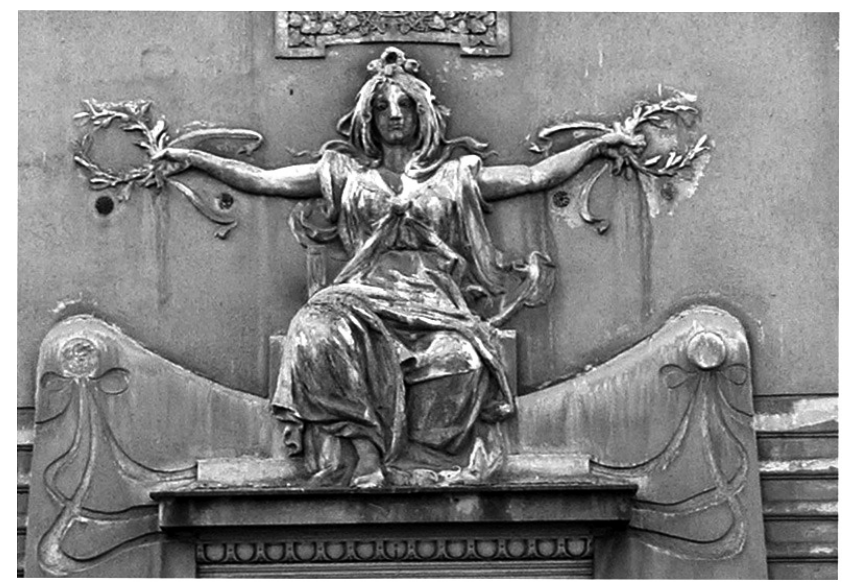

slika 10: Pogačnikova hiša vir: arhiv Robert Simonišek

Odločil se je za relief sedeče ženske figure, z dolgimi spetimi lasmi, ki ima v rokah vejici. Gre za elegantno figuro v razvihrani draperiji, ki z majestetično postavitvijo spominja na srednjeveške upodobitve Marije na prestolu. A tukaj gre za meščanske ideale, za idealizirano, profanizirano podobo ženske iz ulice, eno izmed osrednjih secesijskih tem, ki je zaživela $\mathrm{v}$ nešteto variantah. Motiv ženske, ki je povezana s floro, so oživljali evropski literati in slikarji vseh narodnosti in ga postavljali v različne, nasprotujoče si simbolne kontekste. Poleg Gustava Klimta je največ pozornosti temu ikonografskemu motivu takrat posvečal češki slikar in oblikovalec Alphonse 
Mucha. Na plakatih, razglednicah in naslovnicah različnih revij je $\mathrm{z}$ močno izrazno risbo upodabljal mlade, sanjave ženske enigmatičnega videza, ponavadi ovite v valovita oblačila (Fahr-Becker, 2007, 89-91). Identičnim motivom je Koch lahko sledil v sami reviji Der Architekt, morda kar na naslovnici iz leta 1896 (slika 11). Dejansko gre za tako izrazito razširjen secesijski motiv, da bi ga lahko kot predlogo zasledil tudi kje drugje.

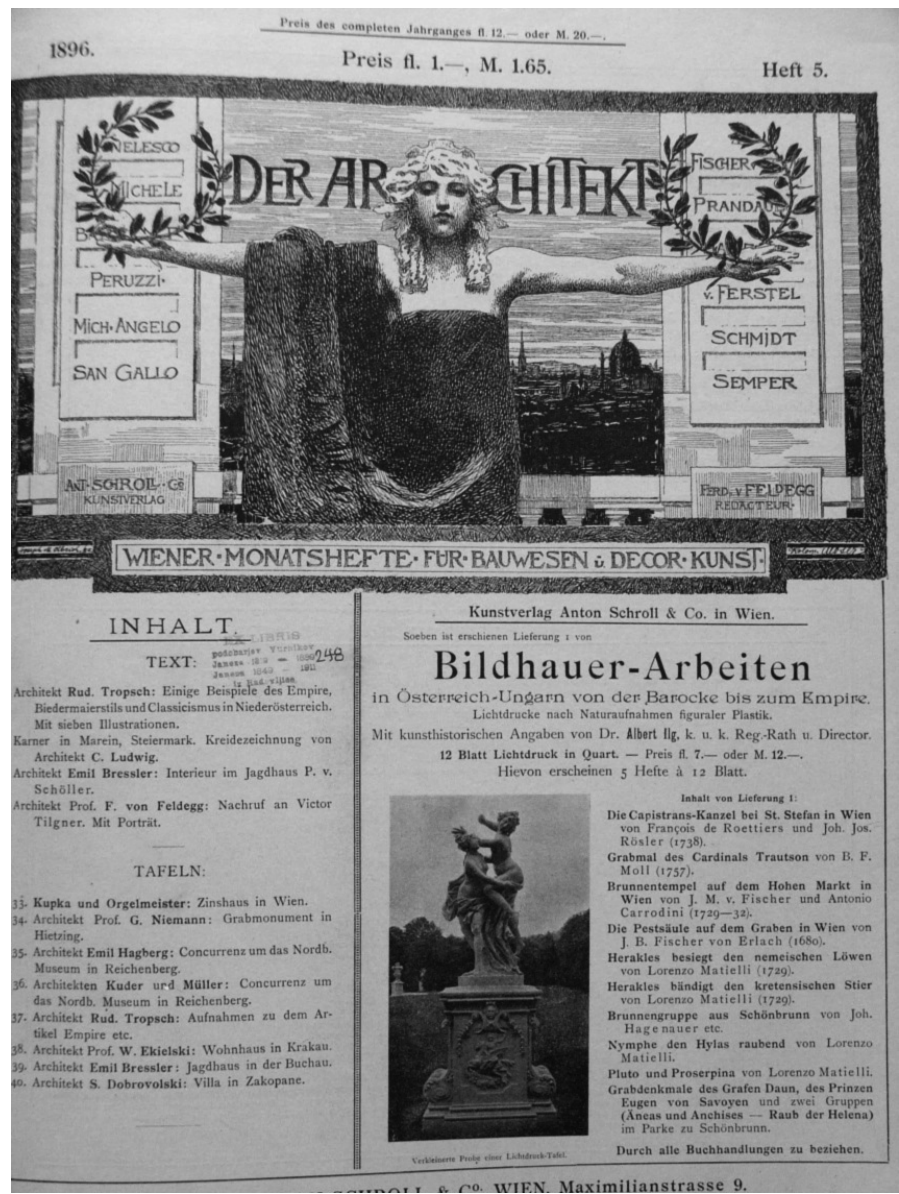

slika 11: Naslovnica Der Architekt 1896 vir: arhiv Robert Simonišek 


\section{Ornament in Meyerjev priročnik}

Secesijski motivi večinoma izvirajo iz rastlinskega sveta, pogosto so geometrični, lahko pa so tudi živalski ali figuralni. Narava je za časa secesije postala prevladujoč filozofski ideal; dejansko lahko številne geometrične ornamente izpeljemo iz naravnih form (Greenhalgh, 2000, 59). Zanimanje za arhitekturni ornament kot konstitutivni element stavbe so kazali že antični pisci, v srednjem veku je odgovore na to ponudilo okraševanje gotskih katedral, kasneje, $v$ renesančnih cerkvah in palačah, je ornament doživljal svojevrstno preobrazbo. Vsako umetnostnozgodovinsko obdobje je v ospredje postavilo določene dekorativne detajle. Številni pisci od antike dalje so razmišljali o najustreznejših, nenavadnih oblikah dekoracije in iskali nove možnosti okraševanja. Seznam vseh vplivnih priročnikov, ki so izšli na evropskih tleh, iz katerih so črpali arhitekti ideje in jih polagali na fasade zgradb v svojevrstne ikonografske kompozicije, je preobsežen. Med 15. in 19. stoletjem so bili objavljeni številni priročniki, ki so omogočali enciklopedičen dostop do znanja ornamentov. V drugi polovici 19. stoletja so razprave o ornamentu postale intenzivnejše in kontroverznejše. Evropski arhitekti, teoretiki in kritiki se nikakor niso strinjali z odgovorom na vprašanje o najbolj idealni obliki ornamenta (Burckhardt, 1985, 57-69). Zanimanje za dekoracijo ni doživelo s secesijo vzpona le v arhitekturi, ampak tudi v slikarstvu in oblikovanju. Spomnimo se, koliko bogato okrašenih stavb v različnih barvnih odtenkih je dobila Ljubljana, koliko sveže okrašenih knjig smo dobili Slovenci z nastopom modernistov, ki so večinoma dobile bogato dekorirano platnice, iniciale ali ilustracije (Komelj, 2008, 117-146). Slovenska arhitektura je sledila dunajski secesiji tudi v smislu okraševanja, saj se je najbolj uveljavil geometrični ornament, medtem ko je recimo v Franciji bilo več navdušenja nad floralnimi prvinami (Moravanszky, 1998, 8).

V nadaljevanju se bom posvetil priročniku Handbuch der Ornamentik, ki ga je napisal Franz Sales Meyer (1849-1927). Koch ga je kupil leta 1889, zgolj eno leto po prvi izdaji. Meyer je svoj vsestranski, pedagoški, pisateljski in risarski talent dokazal s številnimi teksti ter risbami. Od leta 1879 in vse do konca 1. svetovne vojne je poučeval ornamentiko na obrtni šoli v Karlsruheju. Objavil je knjige, ki se večinoma ukvarjajo z ornamentom: Han- 
dbuch der Ornamentik (1888-90), Handbuch der Schmiedekunst (1888), Handbuch der Liebhaberkünste (1889), Musterbuch moderner Schmiedeeisenarbeiten (1888) in skupaj s Theodorjem Krauthom Schreinerbuch (1890). ${ }^{23}$ Meyer in Koch se nista nikoli srečala, gre za posreden vpliv. Priročnik je v osnovi bogata zbirka ornamentov iz vseh stilnih obdobij. Pregled je razdeljen na arhitekturno in ostalo dekoracijo, ornamenti so razvrščeni glede na tip: geometrični, sadni in floralni, umetni, mitološka bitja, trakovi, cizelirani/izrezljani ipd. V njem lahko med drugim zasledimo kvalitetne risbe stolov, kron, oltarjev, heraldičnih emblemov, oklepov iz različnih obdobij. Knjiga bibličnih razsežnosti vsebuje več kot 3000 primerov najrazličnejših dekoracijskih elementov (Meyer, 1993, 1-615). ${ }^{24}$ Ob primerjanju intuitivno naletimo na podobnosti med motivi in dekoracijo ljubljanske historicistične ali secesijske arhitekture. Natančnejša primerjava med detajli, ki jim je Koch lahko sledil $\mathrm{v}$ priročniku in tistim, kar je dejansko vključil na fasadne ploskve kaže, da detajlov ni kopiral: največkrat gre za povzemanje, za spreminjanje značilnosti posameznega ornamenta.

Če pretresemo celoten Kochov opus, ugotovimo, da sta na njegovih secesijskih stavbah v največji meri prisotni rastlinska in geometrična dekoracija. Žival kot motiv nastopa redkeje, izmed figuralnih postavitev je najbolj razširjen fragment ženskega obraza, medtem ko je celopostavna figura pri njem bolj izjema kot pravilo. Za ponazoritev ornamenta, kjer gre za ujemanje med risbo v priročniku in fasado, nam lahko služi meander na Kochovi prulski šoli. Risba meandra v priročniku poteka $\mathrm{v}$ isti smeri, kot je na pročelju ljubljanske stavbe. V posebnem poglavju Meyer razvrsti meandre v skupine: nesimetrične ali tekoče meandre povzete po grških vazah, simetrične, tiste $\mathrm{z}$ dvema ali več linijami. Razlaga v priročniku se nanaša na zgodovinski razvoj, vključno z etimologijo; kot ornament je ta specifično grški, ki ima prednike $v$ asirski in egipčanski umetnosti; najbolje se je formuliral v grškem vaznem slikarstvu in arhitekturi; v rimski umetnosti se je podredil talnim mozaikom; srednjeveški meander se je bolje izrazil v kitajski in japonski umetnosti kot na evropskih tleh; v novih kombinacijah se je revitaliziral $v$ renesansi in se od tega obdobja dalje razvijal v povezavi

23 Vir podatka: http://home.eol.ca/ props/bookshelf.html.

24 Splošen opis vsebine priročnika je nastal na podlagi pregleda posameznih poglavij. 
z rastlinskimi motivi (Meyer, 1993, 144). Za ponazoritev modifikacije nam bo služila Meyerjeva stran iz poglavja o skupini ornamentov, ki jim je skupen človeški organizem, in sicer podpoglavje o maskah in spakah (Meyer, 1993, 108-115; slika 12).

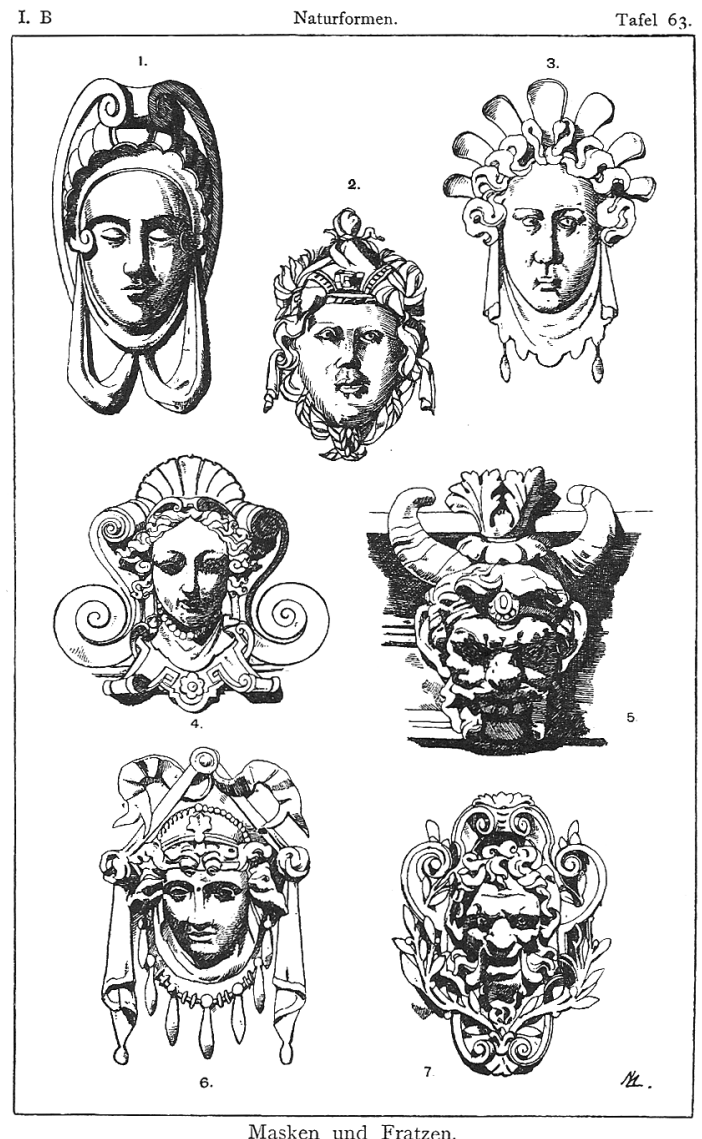

slika 12: Stran iz Handbuch der Ornamentik vir: arhiv Robert Simonišek

Meyer opiše kontinuiteto tega tipa ornamenta, ki se je pojavljal v likovni umetnosti $\mathrm{v}$ številnih variacijah. Začetki segajo $\mathrm{v}$ čas nastanka grške tragedije; nov val svežine $\mathrm{v}$ razvoju so pomenile pompejanske freske; ornament maske je bil znova obujen na različnih koncih Evrope $\mathrm{z}$ renesanso; 
bil je prisoten v vseh kasnejših stilnih obdobjih. Bogastvo in raznovrstnost mask, ki jih je Koch uporabil na fasadah hiš, je na tem mestu težko zajeti. Večinoma so to kiparski dodatki žensk različnih obraznih potez, z dolgimi lasmi, ki krasijo vhode ali višja nadstropja meščanskih hiš. Čeprav Koch ni edini slovenski arhitekt, ki se je pogosto posluževal tovrstne dekoracije, je maska eden izmed njegovih prepoznavnih emblemov in dominanten figuralni ornament: če se na posamezni fasadi pojavlja zgolj en tip maske, drugje zasledimo po več tipov hkrati. Za primerjavo z Meyerjevim priročnikom nam lahko služijo maske na fasadah nekdanje Čudnove, Frischove (slika 13), Zhubrove, Vodnikove hiše in hiše Policijske uprave. Pri teh stavbah je kvaliteta mask izrazitejša. Tudi analiza tega tipa ornamenta pokaže, da maske niso kopirane po priročniku. Venomer so povzeti le detajli, posamezni poudarki so postavljeni v nov ikonografski kontekst in kot celota izzvenijo drugače.

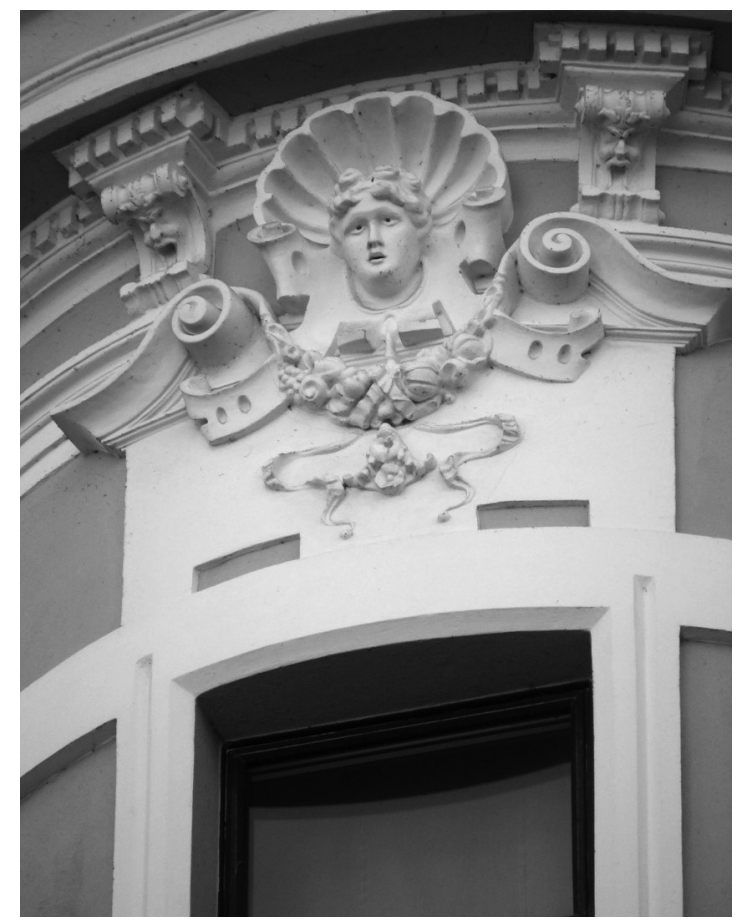

slika 13: Frischova hiša vir: arhiv Robert Simonišek 


\section{VIRI}

Der Architekt, Wiener Monatshefte fur Bauwesen und decorative Kunst, II. Jahrgang, Wien, 1896.

Ver Sacrum, Wien, 1899.

ZL, LJU/494, Zbirka personalnih spisov.

\section{SPLETNI VIRI}

http://www.aeiou.at/aeiou.encyclop.h/h234020.htm http://www.artnet.com/library/03/0368/T036837.asp http://www.planet-vienna.com/spots/Palais/luetzow/luetzow.htm http://www.sbg.ac.at/ger/zelewitz/liwimo/docu/freiold/generated/pdf/lecture.pdf

http://www4.karlsruhe.de/kultur/stadtgeschichte/biographien/f_s_meyer/ http://home.eol.ca/ props/bookshelf.html http://www.khm.at/homeE107.html http://www.stadt-wien.at/index.php?id=burgtheater-wien

\section{LITERATURA}

Burckhardt, R., Ornament und Mythos, Ornament und Askeze, Dunaj 1985.

Fahr-Becker, G., Art Nouveau, Cambridge 2007.

Greenhalgh, P., Art Nouaveau 1890-1914, London 2000.

Huici, F., Klimt, New York 1989.

Komelj, M., Ivan Vavpotič, Narodna galerija, Ljubljana 1987, 11-56. 
Komelj, M., Med svetlim polmrakom in konturami življenja, Slovenski impresionisti in njihov čas 1890-1920, Narodna galerija, Ljubljana 2008, 117-146.

Mallgrawe, H. F., Gottfried Semper: architect of the nineteenth century, London 1996.

Meyer, F.S., Illustriertes Handbuch der Ornamente, Sttutgart 1993.

Moravanszky, A., Competing visions, Aesthetic Invention and Social Imagination in Central Europe Architecture 1867-1918, Massachusetts 1998.

Prelovšek, D., Ljubljanska arhitektura Hribarjevega časa, Grafernauerjev zbornik, Ljubljana 1996, 597-606.

Simonišek, R., Arhitekt Ciril Metod Koch, Ljubljana 2007 (magistrsko delo, Oddelek za umetnostno zgodovino, Filozofska fakulteta, Univerza v Ljubljani, tipkopis)

Wacha, G., Prašelj, N., Koch Ciril Metod, Osterreichisches biographisches Lexikon 1815-1950, VI. Band, Wien, 1969, 156.

Zerbst, R., Gaudi, Koln 1997. 